oxygen toxicity, they do not exclude the possibility that other effects may exist, for example, oxidation of thiol groups of enzymes.

I thank Mr. C. Gilchrist for assistance and Mr. F. Wanless for the photomicrographs.

\section{A. C. Allison}

National Institute for Medical Research, London, N.W.7.

${ }^{1}$ Bean, J. W., Physiol. Rev., 25, 1 (1964).

${ }^{2}$ Matteo, R. S., and Nahas, G. G., Science, 141, 719 (1963).

Rutter, W. J., Proc. Fourth Intern. Congr. Biochem., Vienna, 6, 21 (1960).

- Heppleston, A. G., and Simnett, J. D., Lancet, i, 1135 (1964).
Allison, A. C., and Arnstein, H. R. V., Biochim. Biophys. Acta, 49, 566 (196i).

- Porterfield, J. S., and Allison, A. C., Virology, 10, 233 (1960).

${ }^{7}$ Schrek, R., Amer. J. Cancer, 28, 389 (1936).

${ }^{8}$ Allison, A. C., and Mallucei, L., J. Exp. Med. (in the press). - Bitensky, L., in Ciba Found. Symp. Lysosomes, edit. by de Reuck, A. V. S.,
and Cameron, M. P., 362 (Londen: Churchill, 1963).

${ }^{10}$ Mengel, C. E., and Kann, H. E., J. Clin. Invest., 43, 1247 (1964).

${ }^{11}$ Weissman, G., and Dingle, J. T., Exp. Cell Res., 25, 207 (1962).

${ }^{12}$ Weissman, G., and Thomas, I., J. Clin. Invest., 43, 1254 (1964).

1s Tappel, A. L., Saivant, P. L., and Shibko, S., in Ciba Found. Symp: Lysosomes, edit. by de Reuck, A. V. S., and Cameron, M. P., 78 (London, Churchill, 1963).

14 de Duve, C., and Beaufay, H., Biochem. J., 78, 610 (1959).

$1 s$ Allison, A. C., and Mallucci, I., Nature, 208, 1024 (1964).

${ }^{10}$ Cohn, Z. A., and Wiener, E., J. Exp. Med., 118, 1009 (1963).

\title{
DELINEATION OF THE THYMIC AND BURSAL LYMPHOID SYSTEMS IN THE CHICKEN
}

\author{
By Dr. MAX D. COOPER*, Dr. RAYMOND D. A. PETERSON $\dagger$ \\ and Prof. ROBERT A. GOOD
}

Pediatric Research Laboratories of the Variety Club Heart Hospital, University of Minnesota, Minneapolis

$I^{\mathrm{N}}$ NVESTIGATIONS of clinical immunological deficiency syndromes have long suggested the existence in man of two distinct populations of lymphoid cells, a division seen most clearly in the Bruton type of sex-linked recessive agammaglobulinæmia in which there is virtually complete failure of plasma cell formation ${ }^{1,2}$ and $\gamma$-globulin production ${ }^{3}$. Many of these patients have never formed detectable antibody. Their immunological failure is only partial, however; they are able to express delayed hypersensitivity ${ }^{4,5}$ and are usually able to reject homografts, although the rejection process is slower and less efficient than normal ${ }^{6}$. Circulating lymphocyte-levels are relatively normal in most instances. Thus, their immunological defect represents a relatively isolated absence of antibody-producing capability and of its cellular and humoral correlates, plasma cells and the immunoglobulins.

It has been possible, since the discovery of the immunological role of the mammalian thymus and the avian bursa of Fabricius, to produce immunological deficiency syndromes in experimental animals, provided the organs are removed in the early neonatal or post-hatching ${ }^{7-17}$ period. However, none of the mammalian models of immunological defect, in the mouse, rabbit, rat, or hamster, has involved absence of immunoglobulins or lack of plasma cells ${ }^{18,15,18-20}$, although all involve some loss of antibody. producing capability. The only model approaching classical agammaglobulinæmia has been that of the chicken bursectomized in the immediate post-hatching period or hormonally bursectomized by treatment with 19-nortestosterone or similar agents during incubation. Such birds produce low levels of antibody to most antigens ${ }^{7,8,21,22}$ and are usually deficient in plasma cells and in $\gamma$-globulin, particularly the $7 S$ component ${ }^{21,23-25}$. Data relating the thymus and bursa to reactions of delayed hypersensitivity are inconclusive ${ }^{21,26}$. Skin homograft immunity has been variably affected by neonatal thymectomy in different series of experiments ${ }^{21,27,28}$, but has been quite consistently uninfluenced by bursectomy.

Szenberg and Warner ${ }^{29}$, in 1962, on the basis of investigations of hormonally bursectomized chickens, some of which also had an atrophied thymic cortex, originally postulated a dissociation of immunological function based on thymic versus bursal influence. Since that time, additional evidence for this immunological dissociation has been forthcoming from several laboratories $26,27,29-31$. Further, the investigations of Peterson et al..$^{32}$ established

* Postdoctoral Research Fellow, U.S. Public Health Service.

$\ddagger$ American Legion Memorial Heart Research Professor of Pediatrics and Microbiology. the role of the bursa in visceral lymphomatosis. This virus-induced malignancy seldom if ever occurs in bursectomized birds, while thymectomized chickens seem to be as susceptible as controls.

The chicken model, then, seemed to offer the greatest potential for separating the two cell systems experimentally, systems so clearly separated in that extraordinary 'experiment of Nature', sex-linked recessive agammaglobulinæmia. The work to be described involved a combination of sub-lethal irradiation with bursectomy, thymectomy, or both in the immediate post-hatching period in chickens. It has enabled us to produce an experimental model of agammaglobulinæmia, and to define the thymic and bursal systems in the chicken. The findings suggest that the thymus-dependent tissue is basic to immunological recognition, and that it interacts with the bursa-dependent lymphoid tissue which might be termed the production system for antibody. They suggest, too, that all the experiments in mammals demonstrating immunological deficiency following removal of the thymus or appendix, or both, have affected thymusdependent lymphoid tissue, that is, recognition.

On the day of hatching, White Leghorn chickens were divided into five groups. One group was surgically thymectomized, another surgically bursectomized, and a third subjected to both procedures. The following day these birds and an unoperated group were irradiated with $600 \mathrm{r}$. (conditions of irradiation: $220 \mathrm{kV}, 15 \mathrm{~m} . \mathrm{mp}$, with $0.25 \mathrm{~mm}$ copper filtration at a dose rate, in air, of $45 \mathrm{r}$./min). In a previous experiment $700 \mathrm{r}$. was the $L D_{60}$ dosage for 2-day-old chickens. All the irradiated animals plus a control unirradiated group were housed together under standard poultry housing conditions.

At the age of 40 days each animal was injected intraabdominally with $20 \mathrm{mg}$ of crystallized bovine serum albumin (Armour) in saline and $10^{9}$ killed Brucella abortus organisms (U.S. Department of Agriculture). Nine days later the birds were bled and killed. Spleen sections from each animal were prepared for staining with methyl green-pyronin ${ }^{33}$ and hæmatoxylin and eosin. Thymus and bursa tissue sections were also stained with hæma. toxylin and eosin. Assays for antibody to bovine serum albumin were performed by a tube hæmagglutination technique using bis-diazotized benzidine linkage of bovine serum albumin to rabbit erythrocytes ${ }^{34}$. Antibody to Brucella was assayed by a standard tube bacterial agglutination method. Microimmunoelectrophoresis of sera from each group of animals was performed by the method of Scheidegger ${ }^{85}$ with a $0.05 \mathrm{M}$ borate phosphate 


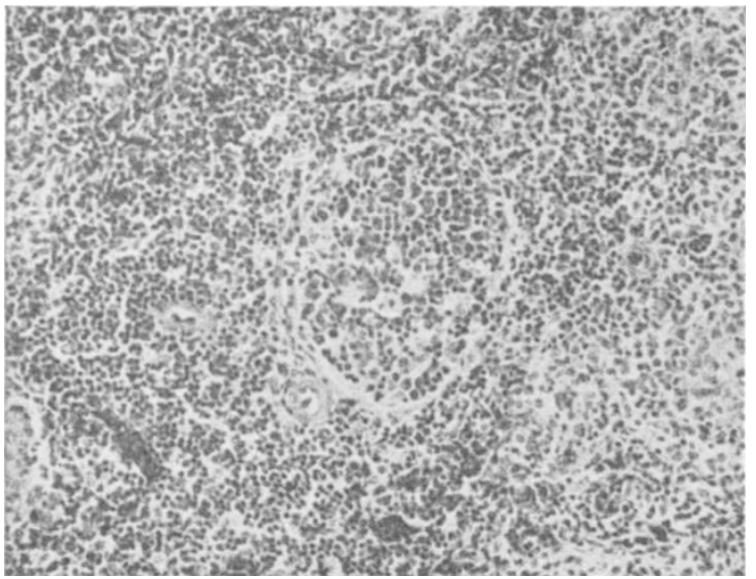

Fig. 1. Section of a normal chicken spleen showing the bursa-dejendent follicle and surrounding thymus-dependent lymphoid component (hæmatoxylin and cosin; $x<.166$ )

buffer at $p H$ 8.2 , using sorum from rabbits hyperimmuno to whole chicken sorum.

In the chicken spleen there are two distinctly different types of lymphoid tissue. One is seen along the small arteries and arterioles, as sheaths of small lymphocytes or as scattered clusters composed of large and small lymphocytes, lymphoblasts, primitive reticular cells, and frequent mitotic figures. This represents the white pulp of the spleen, the bulk of its lymphoid tissue, and it becomes apparent in normal ehickens in the immediate post-hatching period. We found that it was markedly reduced in thymectomized-irradiated and thymectomizedburscetomized-irradiated chickens. Such depletion has been noted previously in chickens subjected to neonatal surgical thymectomy ${ }^{30}$ and in birds with testosteroneinduced thymic cortical damage ${ }^{21}$. This component was not significantly altered in our other experimental groups. This lymphoid tissue we consider the thymus-dependent lymphoid tissue of the chicken.

There is a second type of lymphoid tissue in the chicken spleen, clearly differentiable from the thymus-dependent type both in morphologic appcarance and in the time of its development. It is seen as sharply circumscribed round or oval lymphoid follicles (Fig. 1) which seem to be encased by a thin fibrous membrano and which always lie in juxtaposition to a small artery. These follicles bear a striking morphological resermblance to the follicles of the bursa of Fabricius itself (Fig, 2). They are even more clearly separable from the other spleen components when

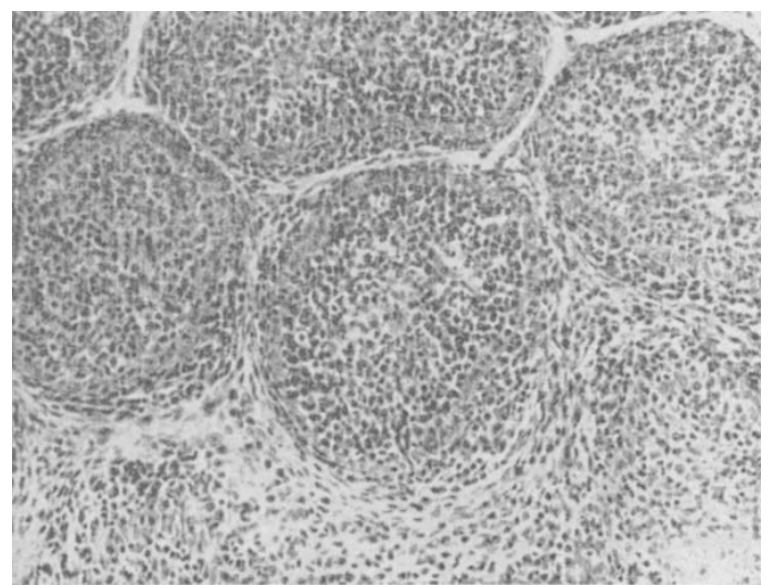

lig. 2. Bursa section showing follicular structure (hæmatoxylin and eosin; $\times 0.166)$ stained with methyl groon-pyronin because of the eytoplasmic pyroninophilia of the constituent cells (Fig. 3). Those structures, in contrast to the thymus-dependent white pulp, develop rolatively late in the normal chicken, about tho fourth to fifth week of lifo. Thus, the thymusdependent tissue is quite well developed by the time the bursa-like follicles aro first recognizable morphologically.

These bursa-like follicles were not found in splcen scctions of any bird irradiated following nconatal bursectomy or bursectomy-thymectomy, but were consistently present in members of all the other groups regardloss of prior manipulation (Table 1). Plasma colls were also consis tently absent in tho bursectomized-irradiated or bursectomized-thymectomizod-irradiated chickens, but were readily found in all the other groups. 'Thus, we consider the bursa-dependent Jymphoid system to include these bursa-like lymphoid folliclos and the plasma coll system.

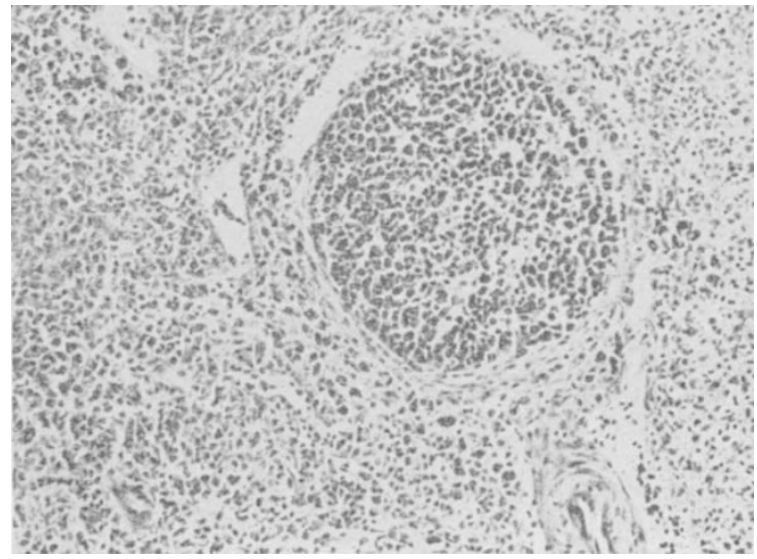

Fig. 3. Bursa-dependent follicle in the spleen showing the pyroninophilia of the enclosed cells (methyl green-pyronin; $x e .166$ )

Table 2 gives the antibody titres to bovine serum albumin and Brucella in the five experimental groups. None of the animals subjected to both bursectomy and irradiation, and lacking bursa-like follicles and plasma colls in the splecn, doveloped dotectable antibodies to these antigens. In addition, the sera of these birds showed no detectable $\gamma^{M}(19 S)$ or $\gamma^{G}(7 S)$ globulins on immunoelectrophoresis, although theso bands woro rogularly soon in the sera of chickens of the other groups (Fig. 4). This is not a quantitative technique, but the

I'able 1. BURSA-DEPENDENT FOLLICLES AND PrasMa CrLAS IN SPLERKS

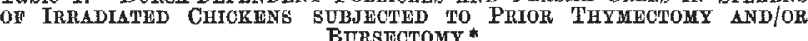

\begin{tabular}{lcc}
\multicolumn{1}{c}{ Group } & $\begin{array}{c}\text { Bursa-dependent } \\
\text { follicles }\end{array}$ & $\begin{array}{c}\text { Plasma } \\
\text { cells }\end{array}$ \\
Bursectomized-irradiated & $0 / 9$ & $0 / 9$ \\
Bursectomized-thymectomized-irradiated & $0 / 8$ & $0 / 8$ \\
Thymectomized-irradiated & $11 / 13$ & $13 / 13$ \\
Control-irradiated & $14 / 15$ & $15 / 15$ \\
Control-non-irradiated & $15 / 15$ & $15 / 15$
\end{tabular}

* The denominator in each case is the number of animals examined; the numerator is the number of animals in which the structure or cell type was found in any of the several sections from each animal.

Table 2. Primary antibody Rusponse of Irradiatod Chickens SDBJECTED TO PRTOR THYMKCTOMY AND/OR BURSECTOMY

Group

$$
\begin{aligned}
& \text { Brucella abortus Bovine serum albumin }
\end{aligned}
$$

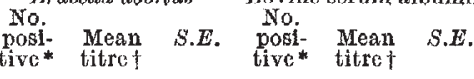

Bursectomized-irradiated Bursectomized-thymectom -

Thymectomized-irradiated

$\begin{array}{lrrrrrr}\text { Thymectomized-irradiated } & 7 / 12 & 4 \cdot 83 & 1 \cdot 12 & 7 / 12 & 2 \cdot 83 & 0 \cdot 67 \\ \text { Control-irradiated } & 16 / 17 & 7+30 & 0 \cdot 86 & 14 / 18 & 4 \cdot 18 & 0.52 \\ \text { Control-non-irradiated } & 22 / 22 & 7.45 & 0.71 & 16 / 20 & 4 \cdot 30 & 0 \cdot 61\end{array}$ * The denominator is the number of chickens for which sera were available te numeralur is the number of ehiekeng with detectable antibody.

t'he reciprocal of each antibody titre was converted to $\log _{8}+1$; the means and stand 


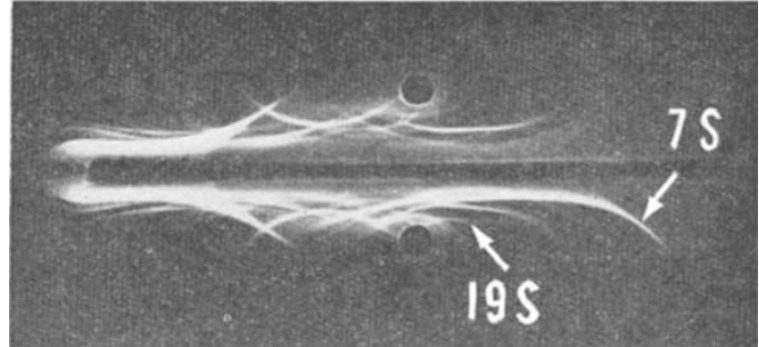

Fig. 4. Microimmunoelectrophoresis of sera from bursectomized-
irradiated chicken (top) and normal chicken (bottom). The antiserum used was from rabbits hyperimmune to whole chicken serum

results suggest that $\gamma$-globulin is absent in the bursectomized-irradiated animals.

Thus, we have 7-week-old chickens, bursectomized and irradiated in the early post-hatching period, which are uniformly agammaglobulinæmic, entirely lacking in plasma cells, and incapable of producing detectable antibody to two antigens of different types. Their spleens have no follicular development of the bursa type; their thymuses are morphologically normal (Fig. 5) as is the thymus-dependent lymphoid development in their spleens.

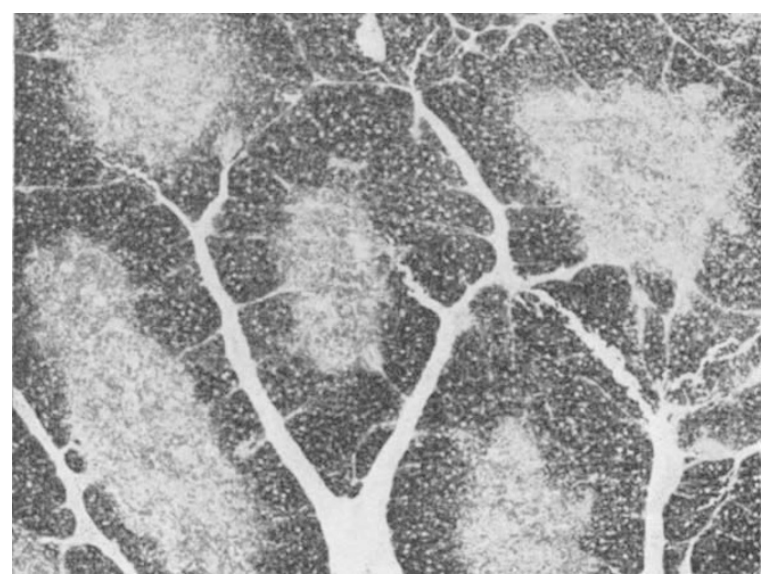

Fig. 5. Normal-appearing thymus of a bursectomized-irradiated chicken (hæmatoxylin and eosin; $\times c .27$ )

It is of interest that significant suppression of antibody. forming ability was also observed in the thymectomizedirradiated birds. Significant depression of antibody responses has occasionally been observed in groups of chickens thymectomized at hatching ${ }^{31}$, but in most instances such birds have had relatively normal antibody levels. The results of the present series suggest that the thymus-dependent tissue in the chicken spleen is sufficiently developed at hatching to respond adequately to antigenic challenge, and that it can continue to do so in the maturing chicken despite the absence of the thymus itself.

These results offer new perspectives not only of the many bursectomy experiments, beginning with the historical work of Glick et al. ${ }^{7}$, but also on the recent thymus work.

Generally, the bursectomy investigations, whether the ablation was surgical or chomical, have involved a quantitative suppression of plasma cells, immunoglobulins, particularly the $7 \mathrm{~S}$ component, and antibody production. Results within series and between series have been quite variable, even allowing for differences in method and strain of chicken. Quite consistent with this picture of residual capacity for antibody production has been the failure to find characteristic morphological changes in the spleens of hormonally or surgically bursectomized chickens, except for the dearth of plasma cells ${ }^{21,36}$.
The effect of bursectomy on the peripheral component of the bursal lymphoid system is seen clearly only in the irradiation model in which the unmistakable bursa-like follicles are eliminated. Since surgical bursectomy alone immediately after hatching does not prevent the development of these follicles, 'peripheralization' of this lymphoid development is apparently well under way at the time of hatching although the follicles themselves are not recognizable morphologically until 4-5 weeks of age.

Treatment of chickens with testosterone propionate during the early embryonic period produces a striking reduction in the bursa-dependent follicles in some of the treated birds. The thymic damage in these birds led Warner et al. ${ }^{21}$ to associate this reduction or absence of splenic follicles with the influence of the hormone on the thymus. We believe, however, that the splenic follicles they were quantitating were the bursa-dependent follicles, although they did not differentiate these two forms of lymphoid tissue.

The bursa system is brought out in bold relief in another context. As noted earlier, Peterson et al. ${ }^{32}$ recently showed that the presence of the bursa of Fabricius is necessary for the development of the avian leukosis, visceral lymphomatosis. We might expect, if the concept of the bursa system is valid, to find exaggeration of the bursal follicles in visceral lymphomatosis. This was described ten years ago by Lucas et al. ${ }^{37}$, who found that infection of ehickens with the virus of avian leukosis resulted in a three-fold increase in the quantity of follicular lymphoid tissue (bursa-dependent tissue in our view). They stated clearly that visceral lymphomatosis did not involve the white pulp (thymus-dependent tissue). They regarded the abnormally proliferating structures of the spleen as ectopic lymphoid structures, although they noted similar structures in normal chickens which were less numerous and less dramatic. The similarity of the structures involved in this form of malignancy and the normal bursal follicle is apparent when Fig. 6 is compared with Fig. 1.

Since the peripheral component of the thymic lymphoid system develops very early compared to the bursal follicles, the role of the thymus has evidently been partially masked in the earlier investigations involving thymectomy immediately after hatching. The variable effects on skin grafts and delayed allergy may well reflect slight strain differences, or even individual differences, in the degree of this peripheral development at the time of hatching. That the chicken thymus, like the thymus of mice, rats, rabbits, and hamsters, has a role in antibody production is shown in the work recorded here in which the peripheral development was reduced by radiation. The response of the thymectomized-irradiated animals

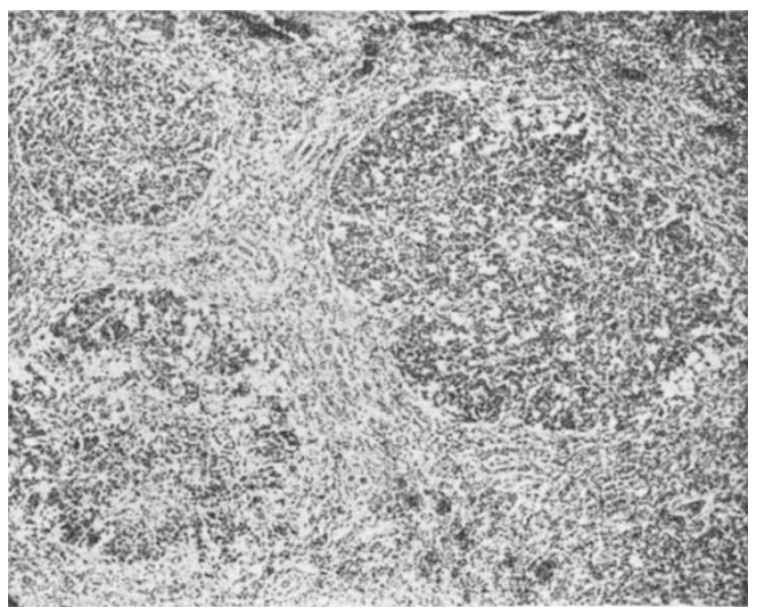

Fig. 6. Spleen section of ehicken with early visceral lymphomatosis, showing exaggeration of involved bursa-dependent follicles (hæmatoxylin and eosin, $x$ c. 166) 
was significantly lower than that of the irradiated controls. In the postulated two-coll system of antibody produstion, the thymus-dependent cells apparently provido the recognition mechanism. The bursa system will continue to form plasma cells and produce immunoglobulins when tho thymus system is awry, but its efficiency in terms of specificity is much reduced. We believe that this is what we and other investigators have observed in thymectomizod mice: appreciable numbers of plasma cells, relatively normal levels of immunoglobulins, but complete loss of capacity for spocific antibody rosponse to some antigens, a variable loss of responsiveness to other antigens, and a normal level of ruactivity to still others ${ }^{11,12,18}$.

It seoms probable that a thymus-typo of function is exercised by the appendix of the rabbit, and perhaps by other organs in that and other species. The investigations which demonstrated this function of the rabbit appendix experimentally had as their point of departure morphological similaritios of the appendix to the chicken bursa ${ }^{38-40}$. In addition, both of these tissues, as woll as the thymus, have a similar embryological origin, either in close association with or directly from the gut epithe.

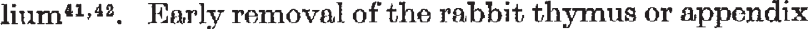
or both curtailed specific antibody production ${ }^{39,40}$, but it left intact the plasma cells and a portion of the follicular lymphoid structure in such tissues as the spleen and lymph nodes. Indeed, we ${ }^{43}$ observed plasmacytosis in the lymphoid tissues, 'autoirmmune' processes, arnyloido. sis, and at least normal immunoglobulins. It appears that even the thymectomized-appendectomized rabbit retains the mammalian equivalent of the bursal system, and that its locus is another of tho gut-epitheliumassociated lymphoid organs.

In sex-linked recossive exammaglobulinamia, the Bruton type, the patients scem to have a loss analogous to that of the bursectomized-irradiated chickens of the present study, as noted earlier. These ohildren have normal thymic morphology and usually have normal numbers of small lymphocytes in the peripheral blood. They recognize 'foreignnoss', develop delayed allergy, and usually reject skin homografts, though by a slow abnormal process. By contrast, they are almost completely lacking in plasma cells, in true follicles in the lymphoid tissues, and in capacity to form any of the immunoglobulins or circulating antibody. Especially striking in the present contoxt is the failure of dovelopment of palatine or pharyngeal tonsils in these patients 44,45 . The human tonsils show close morphological resemblances to the chicken bursa of Fabricius, develop in close association with the epithelium of the gut, and have a similar ontogonetic history, reaching maximum development prior to puberty and then undergoing striking involution.

Thus, it seems more important than evor to test tho hypothesis that a mammalian equivalent of the bursa may exist in the palatine and pharyngeal tonsils, or in other gut-epithelium-associated lymphoid tissue such as the intestinal tonsil or sacculus rotundus of the rabbit. This work is in progross.

Many problems, both clinical and basic, take on new porspoctives if wo consider that there is a two-way division in tho lymphoid systom. The first, which might be termed 'horizontal', is the distinction betweon 'central' gut-epithelium-assogiated lymphoid tissues (the thymus, bursa of Fabricius, appondix, and other tissues to be defined) and 'peripheral' lymphoid tissues, primarily the spleen and lymph nodes. The central tissues aro source tissues, using the terminology of Beard ${ }^{48}$, who described the thymus in these terms bofore 1900. Tho peripheral tissues aro derivative in ontogenetic development, depondent on the central tissues in late embryonic and early postnatal life, but apparently relatively autonomous in the mature organism.

Tho second division, termed 'vertical', is based on the Bruton type of agammaglobulinæmia and the chicken model of agammaglobulinæmia just described. It places in one category the bursa of Fabricius (an equivalent unidentified tissue in mammals), the bursa-like follicles of the spleen, nodes, and other tissues (clearly present in mammals), and the plasma cells; and in the other the thymus, other thymus-like central lymphoid tissue, the white-pulp type of lymphoid development in the peripheral tissues, and the small lymphocytes. Functionally, wo see this vertical division as immunological recognition and information on one hand, and specific antibody production on the other.

We thank Mr. Molvin Schwartz for his assistanco, and Miss Dolores C. Breen for help with the photomicrographs.

This work was aided by grants from the National Foundation, the American Cancer Society, the American Heart Association and the U.S. Public Health Service (HE-02085, $A I-00798$ and 5T1-HE-5462).

${ }^{1}$ Good, H. A., Amer. J, Dis. Child., 88, 625 (1954),

Cralg, J. M., Gitlin, D., and Jewett, T. C., Amer. J. Dis, Child., 88, 626 (1954).

s'Braton, O. C., Pediatrics, 0, 722 (1952).

Kulneff, N.. Pedersen, K. O., and Waldenström, J., Schweiz. Med. Wehnschr., 85, 363 (1055).

Porter, H. M., Amer, J, Dis. Child., 90, 617 (1955).

'Good, R. A.. Kelly, W. D., Rotstein, J., and Varco, R. L., Progr. Allergy, 6, 187 (1962).

'Gliek, 13., Chang, T. S., and Jaap, R. G., Poultry Sci., 35, 224 (1956). ${ }^{8}$ Mueller, A. P., Wolfs, I. R., and Meyer, R. K., J. Immunol., 85, 172
(1960).

Archer, O., and Pierce, J. C., Fed. Proc., 20, 26 (1961)

${ }^{10}$ Miller, J. F. A. P., Lancet, ii, 748 (1961).

${ }^{11}$ Good, R. A., Dalmasso, A. P., Martinez, C., Archer, O. K., Pierce, J. C. and Papermaster, B. W., J.'Exp. Med.,116, 773 (1962).

${ }^{12}$ Miller, J. F. A. P., Proc. Roy. Soc., B, 156, 415 (1962).

${ }^{13}$ Arnason, B. G., Jankovic, B. D., Waksman, B. H., and Wennersten, C., J. Exp. Med, 116, 177 (1962).

Jankovic, B. D., Waksman, B. H., and Arnason, B. A., J. Exp. Med. 116, 159 (1962).

${ }^{15}$ Sherman, J. D., Adner, M. M., and Dameshek, W., Blood, 28, 375 (1984)

Defendi, V., Roosa, R. A., and Koprowski, H., in The Thymus in Immunobiology, edit. by Good, R. A., and Gabrielsen, A, 1., 504 (Hoeber-Harper, New York, 1964).

${ }^{17}$ Roosa, R, A., Wilson, D., and Defendi, V., Fed. Proc., 22, 599 (1963).

${ }^{18}$ Humphrey, J. II., Parrott, D. M. V., and kast, J., Ymmunology, 7,419 (1964).

Archer, O. K., in The Thymus in Immunobiotony, edit, by Good, R. A., and Gabrielsen, A. E., 432, 435 (Hoeber-Harper, New York, 1964).

${ }_{20}$ Waksman, B. H., Arnason, B, G., and Jankovic, B. D., J. Exp. Med, ,116, $187(1962)$.

${ }^{21}$ Warner, N. L., Szenberg, A., and Burnet, F. M., Austral. J. Exp. Biol. , 40, $373(1962)$

22 Papermaster, B. W., Frledman, D. I., and Good, R. A., Proc. Soc. Exp Biol. and Med., 1io, 02 (1962).

${ }^{23}$ Long, P. L., and Pierce, A. E., Nature, 200, 426 (1963).

${ }^{24}$ Ortega, L. G., and Der, B. K., Fed. Proc., 23, 546 (1964).

${ }^{95}$ Carey, J., and Warner, N. L., Nature, 203, 198 (1964).

Janković, B. D., and Isvaneski, M., Int. Arch. Allergy Appl. Immunol., 23, 188 (1963).

${ }^{27}$ Aspinall, R. L., Meyer, R. K., Gractzer, M. A., and Wolfe, H. R., J. Immunol., 80,872 (1963)

${ }^{28}$ Xunis, E. J., Cooper, M. D., and Good, R. A. (unpublished results).

${ }^{20}$ Szenberg, A., and Warner, N. I., Nature, 194, 146 (1962).

${ }^{30}$ Jankovic, B. D., and Isakovic, K., Intern. Arch. Allergy Appl. Immunol., 24, 278 (1964)

${ }^{32}$ Graetzer, M. A., Wolfc, H. R., Aspinall, R. I., and Meyer, R. K., J. Immunol., 90,' 878 (1963).

${ }^{2}$ Peterson, R. D. A., Burmester, B. R., Frederickson, T. N., Purchase, H. G., and Good, R. A., J. Nat. Caneer Inst., 32, 1343 (1964).

as Opstad, A. M., Stain Technol., 34, 293 (1959).

${ }^{34}$ Gordon, J., Rose, B., and Sehon, A. H., J. Exp. Med., 108, 37 (1958).

ss Scheidegger, J. J., Intern. Arch. Allergy and Appl. Immunol., "\%, 103 (1955).

${ }^{36}$ Isakovic, K., and Janković, B. D., Intern. Arch. Allergy and Appl. Immunol., 24, 296 (1964).

${ }^{37}$ Lucas, A. M., Denington, E. F., Cottral, G. E., and Burmester, R. R., Poultry Sci., 38, 571 (1954).

${ }^{8}$ Archer, O. K., Sutherland, D, E, R., and Good, R. A., Nalure, 200, 337 (1963).

${ }^{30}$ Sutherland, D. E, R., Archer, O, K., and Good, R. A., Proc, Soc, Exp, Biol. and Med., 115, 673 (1064).

40 Archer, O, K., Sutherland, D. E. R., and Good, R, A., Lab. Invest., 18, 250 (1064).

41 Aucrbach, R., Develop, Hiol., 3, 396 (1061)

${ }^{49}$ Ackerman, G. A. and Knouff, R. A, J, Anat, 104, 163 (1959),

so Sutherland, D. F. R., Archer, O. K., Peterson, R. D. A., Eckert, E., and Good, R. A., Lancet (in the press),

4 Neuhauser, E, B, D. (personal communication).

4 Margulis, A. R., Feinberg, S. B., Lester, R. G., and Good, R. A., Radiology, 69, 854 (1057).

46 Beard, J., Anat. Anzeiger, 9, 476 (1894). 